\title{
The Appellate Body's Power to Interpret the WTO Agreements and WTO Members' Power to Disagree with the Appellate Body
}

\author{
Yuka Fukunaga \\ Waseda University, Tokyo, Japan \\ yuka-fukunaga@waseda.jp
}

\begin{abstract}
The United States criticizes the Appellate Body for 'making law' by interpreting and applying the World Trade Organization (WTO) agreements in disregard of the intention of WTO members. The criticism of the United States is not without legitimate basis in that Members have few tools with which they may weigh in on the interpretation of the WTO agreements, even if the Appellate Body makes an erroneous interpretation. As much as the Appellate Body's contribution to the security and predictability of the multilateral trading system warrants praise, the dysfunction of legislative and political mechanisms to counterbalance the growing de facto 'authority' of the Appellate Body should be a cause for concern. Against this background, this article proposes a new mechanism that would allow Members to disagree with interpretations by the Appellate Body and pronounce their own interpretations of the WTO agreements. The mechanism would be built upon 'interpretative declarations.'
\end{abstract}

\section{Keywords}

Appellate Body - authoritative interpretation - Guide to Practice on Reservations to Treaties - interpretative declaration - overreach - precedent - subsequent agreement and subsequent practice - Vienna Convention on the Law of Treaties

* LLD (University of Tokyo); LLM (University of Tokyo); LLM (University of California, Berkeley); LLB (Hitotsubashi University). An earlier version of this article was presented at the Sixth Biennial Conference of the Society of International Economic Law (SIEL) in July 2018 in Washington, DC. The author is grateful for comments and suggests from participants at the conference, in particular, Professor Giorgio Sacerdoti and Professor Dr. Hélène Ruiz Fabri. All errors are the responsibility of the author. The research leading to this article was supported by JSPS KAKENHI Grant Number 18Ko1284. 
The United States has been blocking the appointment and reappointment of Appellate Body members and seeks to justify its actions by raising various concerns about the practice of the Appellate Body, ${ }^{1}$ the most significant of which is, for the United States, its interpretative approach of 'adding to or diminishing U.S. rights or obligations by not applying the [World Trade Organization (WTO)] agreements as written.' ${ }^{2}$ According to the United States, concerns about the Appellate Body's interpretative approach abound in various areas including procedural issues such as its disregard for the mandatory 9o-day deadline for circulating reports under Article 17(5) of the Understanding on Rules and Procedures Governing the Settlement of Disputes (DSU) ${ }^{3}$ as well as substantive issues such as its restrictive interpretation of the definition of trade-distorting subsidies. ${ }^{4}$ The United States further insists that these concerns are exacerbated by the Appellate Body's practice of overreaching its mandate by making findings that are not aimed at resolving specific disputes and by treating its past reports as precedent. ${ }^{5}$

On one hand, the act of the United States to block the appointment and reappointment of Appellate Body members deserves criticism as it undermines the impartiality and independence of the Appellate Body members ${ }^{6}$ and could jeopardize the rules-based multilateral trading system. ${ }^{7}$ Moreover,

1 An analysis from an institutional perspective suggests that the blocking of the reappointment is a manifestation of a trilemma of judicial independence, judicial accountability and judicial transparency that is inevitable in all international courts and tribunals. Jeffrey $\mathrm{L}$ Dunoff and Mark A Pollack, 'The Judicial Trilemma' (2017) 111 AJIL 225, 226-27, 260-71; See also Isabelle Van Damme, "The Application of "The Judicial Trilemma" to the WTO Dispute Settlement System' (2017) 111 AJIL Unbound 359.

2 United States Trade Representative, '2018 Trade Policy Agenda and 2017 Annual Report of the President of the United States on the Trade Agreements Program' (March 2018) 22-23 $<$ https://ustr.gov/about-us/policy-offices/press-office/reports-and-publications/2018/2018trade-policy-agenda-and-2017> accessed 9 August 2019.

3 Understanding on Rules and Procedures Governing the Settlement of Disputes (1 January 1995) 1869 UNTS 401 (DSU).

4 ibid $23-25$.

5 ibid $26-28$.

6 See Letter from the Living Former Appellate Body Members to the Chairman of the WTO DSB (31 May 2016) <http://worldtradelaw.typepad.com/files/abletter.pdf> accessed 9 August 2019. An author points out that it also violates due process of law under the DSU. ErnstUlrich Petersmann, 'Between "Member-Driven" WTO Governance and "Constitutional Justice”: Judicial Dilemmas in GATT/WTO Dispute Settlement' (2018) 21 JIEL 103, 107.

7 See Statement of Korea, on behalf of Brazil, Canada, the European Union, Guatemala, India, Indonesia, Israel, Jamaica, Korea, Mexico, Morocco, Sri Lanka, Switzerland, Thailand and Viet Nam, at a meeting of the Dispute Settlement Body on 22 June 2016 (2 September 2016) $\mathrm{WT} / \mathrm{DSB} / \mathrm{M} / 380$, para 11.3 . 
it ignores the fact that the clarification of the WTO agreements through the interpretation by the Appellate Body in a consistent and exhaustive manner enormously contributes to the security and predictability of the multilateral trading system.

However, the concerns of the United States are not without legitimate basis in that Members have few tools with which they may weigh in on the interpretation of the WTO agreements, while interpretations made by the Appellate Body increasingly have a de facto 'authoritative' power. Even if the Appellate Body makes an interpretation that appears erroneous in the eyes of many WTO Members, such an interpretation is unlikely to be corrected and is likely to be considered 'authoritative' by subsequent panels. Moreover, the imbalance between the paralyzed decision-making by WTO Members and the growing de facto 'authority' of the Appellate Body may convince certain Members that their 'exclusive' law-making power is being eroded by the Appellate Body. As much as the Appellate Body's contribution to the security and predictability of the multilateral trading system warrants praise, the lack or dysfunction of legislative and political mechanisms to counterbalance the judicial power should be a cause for concern. ${ }^{8}$

Against this background, this article proposes a new mechanism that would allow Members to disagree with interpretations by the Appellate Body and pronounce their own interpretations of the WTO agreements. ${ }^{9}$ The mechanism would be built upon 'interpretative declarations' that are widely recognized under general international law and are frequently used by States. The mechanism may not directly resolve all issues raised by the United States but seeks to address the more fundamental problem of the imbalance between the judicial and the political branches of the WTO. The article argues that, under the current WTO agreements, while the WTO Members do have the power to disagree with interpretations by the Appellate Body and pronounce their own interpretations of the WTO agreements, they lack a proper mechanism to effectively exercise that power. This article considers that the new proposed mechanism would fill the current institutional gap.

At this point, it is important to note that the proposed mechanism is different from other similar mechanisms in important ways. First, the proposed mechanism is different from Articles 16(4) and 17(14) of the DSU, which allow

8 Cf Claus-Dieter Ehlermann \& Lothar Ehring, "The Authoritative Interpretation Under Article IX:2 of the Agreement Establishing the World Trade Organization: Current Law, Practice and Possible Improvements' (2005) 8 JIEL 803, 812-13.

9 This article focuses on interpretations by the Appellate Body, but the arguments would apply to interpretations by panels mutatis mutandis. 
WTO Members to 'express their views' on Appellate Body reports when the reports are adopted at meetings of the Dispute Settlement Body (DSB). Unlike interpretations formulated under the proposed mechanism, views expressed under Articles 16(4) and 17(14) of the DSU do not, and are not intended to, have any legal significance. ${ }^{10}$ In fact, the limited significance of the 'views' under these provisions underlies the concern related to the imbalance between the de facto authority of the Appellate Body and the absence of Member control.

The proposed mechanism is also different from the partial adoption, proposed by the United States in the DSU review negotiations, ${ }^{11}$ which would allow the DSB to decide not to adopt a part of the findings in an Appellate Body report or a part of the rationale behind the findings to increase Member control. ${ }^{12}$ This article considers that the partial adoption would result in a partial but direct modification of an Appellate Body report by the Members and ultimately undermine the impartiality and independence of the Appellate Body. In the meantime, the mechanism proposed by this article would enable a more nuanced check and balance in WTO dispute settlement by allowing WTO Members to make a 'counter-proposal' to the Appellate Body's interpretation.

To lay the groundwork for my proposal on the new mechanism, this article begins with questions regarding the Appellate Body's power to interpret the WTO agreements, and then moves on to questions regarding Members' power to disagree with the Appellate Body's interpretations. Finally, the paper discusses how the new mechanism would be designed and implemented.

10 Views expressed by Members at DSB meetings might have implicitly influenced the thinking of panelists and Appellate Body members, but only in a few limited cases and in an obscure manner. Cf Joshua Paine, ‘The WTO's Dispute Settlement Body as a Voice Mechanism' (2019) 20 JWIT 820. However, openly acknowledging the legal significance of the views would discourage Members from expressing their views at DSB meetings while, generally speaking, Members should be encouraged to express views more actively at DSB meetings. Cosette D Creamer and Zuzanna Godzimirska, 'Deliberative Engagement Within the World Trade Organization: A Functional Substitute for Authoritative Interpretations' (2016) 48 NYU J Intl L \& Pol 413, 452-57.

11 WTO, 'Negotiations on Improvements and Clarifications of the Dispute Settlement Understanding: Further Contribution of the United States on Improving Flexibility and Member Control in WTO Dispute Settlement: Communication from the United States', Special Session of the Dispute Settlement Body (24 October 2005) TN/DS/W/82, 3-4; WTO, 'Flexibility and Member Control: Revised Textual Proposal by Chile and the United States: Communication from Chile and the United States', Special Session of the Dispute Settlement Body (31 May 2007) TN/DS/W/89, 3 .

Flexibility and Member Control (n 11) 1, 3 . 
With respect to the Appellate Body's power to interpret the WTO agreements, the first question concerns the scope of such power: Does the Appellate Body have the power not only to make findings on disputed issues but also to make statements or observations on general interpretative issues that are not directly related to specific disputes before it? This paper answers the question in light of the rules under the DSU as well as policy considerations. The second question concerns the nature of the power: Does the Appellate Body have the power to 'make law' in the sense that it makes interpretations that bind subsequent panels and WTO Members? In particular, this paper assesses the nature of precedential effects of Appellate Body's interpretations.

\subsection{Scope of Interpretations}

Does the Appellate Body have the power to make statements or observations on general interpretative issues that are not directly related to specific disputes before it?

As to the mandate of the Appellate Body, Article 17(1) of the DSU provides that '... [t] he Appellate Body shall hear appeals from panel cases.' According to the Appellate Body, Article 17(1) confers 'jurisdiction' upon the Appellate Body ${ }^{13}$ to 'uphold, modify or reverse the legal findings and conclusions of the panel' pursuant to Article 17(13) of the DSU. The Appellate Body's jurisdiction is further limited by Article $17(6)$, which provides that '[a]n appeal shall be limited to issues of law covered in the panel report and legal interpretations developed by the panel.' Taken together with Articles 6(2) and 7(1) of the DSU, which provide that the scope of a panel's findings is delimited by its terms of reference, the scope of the Appellate Body's jurisdiction to make findings shall be limited to 'issues of law' and 'legal interpretations' in the panel report regarding the 'specific measure' identified and the 'legal basis' provided by the complainant.

While the scope of the Appellate Body's jurisdiction to make findings is explicitly limited by the abovementioned provisions of the DSU, nothing in the DSU imposes limits on the Appellate Body's power to make statements or observations on general interpretative questions in reaching such findings. ${ }^{14}$

13 WTO, European Communities and Certain Member States - Measures Affecting Trade in Large Civil Aircraft, Report of the Appellate Body (18 May 2011) WT/DS316/AB/R, ANNEX III, para $7, \mathrm{fn} 1$.

14 The concept of obiter dicta is not explicitly mentioned in the DSU, but making statements in the nature of obiter dicta is not explicitly or implicitly prohibited by the DSU. Cf Henry Gao, 'Dictum on Dicta: Obiter Dicta in WTO Disputes' (2018) 17 World Trade Rev $509,517-32$. 
It could be inferred from the lack of explicit limits that the Appellate Body has the power to make general statements or observations in reaching findings in a specific case. In fact, the power to decide how to reach findings is inherent in every judicial and quasi-judicial organ. For example, in the process of reaching its findings, a judicial or quasi-judicial organ may consider it necessary to address an interpretative issue not directly disputed between the parties to make its reasoning on the disputed issue more convincing. Alternatively, it may find that a specific issue disputed between the parties is rooted in their disagreement on a general interpretative issue and that the former cannot be resolved without addressing the latter. Contrary to what the United States seemingly argues, ${ }^{15}$ limiting the Appellate Body's power to make general statements or observations could make it difficult for it to make reasoned findings 'to secure a positive solution to a dispute'16 and 'assist the DSB in making the recommendations. ${ }^{17}$

Having acknowledged that the Appellate Body has the inherent power to make statements or observations on general interpretative issues, the question of how the power should be exercised then arises. From a policy perspective, it might be argued that the Appellate Body should be encouraged to address general interpretative issues that may not be directly related to a specific dispute at hand, considering that the WTO dispute settlement is 'a central element in providing security and predictability to the multilateral trading system ${ }^{\prime 18}$ and that the Appellate Body plays a distinct role in securing 'consistency and stability in the interpretation' of the WTO agreements. ${ }^{19}$ Moreover, the mandate of the Appellate Body 'to clarify the existing provisions of' 20 the WTO agreements could be implemented more effectively if it addressed legal issues in a comprehensive and exhaustive manner. ${ }^{21}$ Although pronouncements by the Appellate Body on legal issues that are not strictly necessary to resolve a specific dispute are considered obiter dicta and do not have any legal effects, ${ }^{22}$ they

\footnotetext{
152018 Trade Policy Agenda (n 2) 26-27.

16 DSU, art 3.7.

17 ibid art 11 .

18 ibid art 3.2.

19 WTO, United States - Final Anti-Dumping Measures on Stainless Steel from Mexico, Report of the Appellate Body (30 April 2008) WT/DS344/AB/R, para 160.

20 DSU, art 3.2.

21 Cf Hersch Lauterpacht, The Development of International Law by the International Court (CUP 1982) 37 .

22 Cf Mohamed Shahabuddeen, Precedent in the World Court (CUP 1996) 153-6o; See also WTO, Minutes of the Meeting Held in the Centre William Rappard on 10 January 2001 (Statement of the United States), Dispute Settlement Body (22 February 2001) WT/ DSB $/ M / 96$, para 51 . In particular, such pronouncements should be and can be clearly distinguished from interpretations adopted by Members pursuant to Article IX:2 of the
} 
could 'constitute the principal method' for the clarification and development of the WTO agreements. ${ }^{23}$ It should also be noted that the disputing parties may seek rulings by the Appellate Body in the expectation that interpretations by the Appellate Body would set precedents for future cases. ${ }^{24}$

In practice, however, the Appellate Body has generally limited itself to narrower interpretative issues that are directly related to the case at hand. For example, in US - Wool Shirts and Blouses, the Appellate Body clearly stated that it does 'not consider that Article 3.2 of the DSU is meant to encourage either panels or the Appellate Body to "make law" by clarifying existing provisions of the WTO Agreement outside the context of resolving a particular dispute. ${ }^{25}$ In US - Hot-Rolled, while the Appellate Body denied the existence of a principle that panels may not address issues that need not be addressed to resolve a specific dispute, it eventually upheld the panel's finding on the basis that the panel addressed only issues that it deemed necessary to address in order to resolve the dispute before it. ${ }^{26}$ Moreover, in US - Upland Cotton, the Appellate Body declined to pronounce an interpretation of a term in the WTO agreements because it 'was unnecessary for the purpose of resolving the dispute before it' although it acknowledged that an interpretation in the abstract of the term 'might offer ... some degree of guidance on that issue.'27

The restrained approach of the Appellate Body is consistent with the principal aim of dispute settlement to 'secure a positive solution to a dispute, ${ }^{28}$ according to which, the mandate of the Appellate Body to 'clarify the existing provisions of' the WTO agreements should be implemented only in the context of assisting the DSB to 'achiev[e] a satisfactory settlement of the matter.'29

Marrakesh Agreement. WTO, Argentine - Definitive Anti-Dumping Duties on Poultry from Brazil, Report of the Panel (22 April 2003), WT/DS241/R, para 7.12.

23 Cf Barcelona Traction, Light and Power Company, Limited, Judgment [1970] ICJ Rep 3, Separate Opinion of Judge Sir Gerald Fitzmaurice, para 2.

24 Gregory Shaffer, Manfred Elsig and Sergio Puig, 'The Extensive (but Fragile) Authority of the WTO Appellate Body' (2016) 79 Law \& Contemp Probs 237, 260-61.

25 WTO, United States - Measure Affecting Imports of Woven Wool Shirts and Blouses from India, Report of the Appellate Body (25 April 1997) WT/DS33/AB/R, 19.

26 WTO, United States - Imposition of Countervailing Duties on Certain Hot-Rolled Lead and Bismuth Carbon Steel Products Originating in the United Kingdom, Report of the Appellate Body (10 May 2000) WT/DS138/AB/R, para 73.

27 WTO, United States - Subsidies on Upland Cotton, Report of the Appellate Body (3 March 2005) WT/DS267/AB/R, paras 510, 761.

28 DSU, art 3.7 .

29 ibid art 3.4; An Appellate Body member once pointed out in its separate opinion that ' $[\mathrm{t}]$ he Appellate Body cannot be expected to offer interpretative guidance regarding provisions of the covered agreements in an abstract manner beyond the scope of what is required in a particular dispute. To do so would go beyond the Appellate Body's adjudicatory function 
Moreover, the restrained approach better preserves the legitimacy of the Appellate Body as perceived by WTO Members, many of which are cautious about judicial activism. For example, the United States has repeatedly criticized the Appellate Body for allegedly addressing broader interpretative issues that need not be addressed to resolve a specific dispute before it. ${ }^{30}$ This concern was reflected in the 'Additional Guidance for WTO Adjudicative Bodies,' which was discussed in the context of the DSU review. The Guidance explicitly states that the 'WTO adjudicative bodies should avoid making findings that are not aimed at resolving the dispute. ${ }^{31}$ In addition, a former Appellate Body member once justified the restrained approach by noting that ' $[\mathrm{a}]$ more principled, less-case specific, approach would certainly carry the risk that the Appellate Body would have to correct its reasoning in future appeals,' which 'would be detrimental to the credibility of the Appellate Body and thus affect its legitimacy.32 Assuming that the United States is correct in pointing out that the Appellate Body issued a report, of which more than two-thirds was in the nature of obiter dicta, ${ }^{33}$ such practice should have thus been inhibited. ${ }^{34}$

as contemplated under the DSU.' WTO, India - Certain Measures Relating to Solar Cells and Solar Modules, Report of the Appellate Body (16 September 2016) WT/DS456/AB/R, paras 5.161-5.162. This member continued that 'an Appellate Body report that appropriately disposes of the matter at issue, which ultimately serves to clarify the relevant provisions of the covered agreement, is not only required under the DSU, it is also important in that it allows the DSB to make sufficiently precise recommendations and rulings 'in order to ensure effective resolution of disputes to the benefit of all Members'.

30 See WTO, DSB Minutes of the Meeting (n 22) para 19; See also WTO, Minutes of the Meeting Held in the Centre William Rappard on 23 August 2001 (Statement of the United States), Dispute Settlement Body (2 October 2001) WT/DSB/M/108, para 51; WTO, Minutes of the Meeting Held in the Centre William Rappard on 23 May 2016 (Statement of the United States), Dispute Settlement Body (29 August 2016) WT/DSB/M/379, para.6.4; WTO, Minutes of the Meeting Held in the Centre William Rappard on 28 May 2018 (Statement of the United States), Dispute Settlement Body (31 August 2018) WT/DSB/M/413, paras 10.5-10.9.

31 WTO, Report by the Chairman, Ambassador Ronald Saborio Soto, to the Trade Negotiations Committee, Special Session of the Dispute Settlement Body (21 April 2011) TN/DS/25, A-31. See also Flexibility and Member Control (2005) (n 11).

32 Claus-Dieter Ehlermann, 'Six Years on the Bench of the "World Trade Court": Some Personal Experiences as Member of the Appellate Body of the World Trade Organization' in Federico Ortino and Ernst-Ulrich Petersmann (eds), The WTO Dispute Settlement System 1995-2003 (Kluwer Law International 2004) 499, 528-29.

33 The United States' statement at the adoption of the Appellate Body Report in Argentina Measures Relating to Trade in Goods and Services (DS453); WTO, Minutes of Meeting Held in the Centre William Rappard on 9 May 2016, Dispute Settlement Body (20 June 2016) WT/ DSB/M/378, para.2.6; See also 2018 Trade Policy Agenda (n 2 ) 27.

34 Nevertheless, it should also be recalled that which issues are necessary to be addressed to resolve a dispute is not clear-cut and has to be decided by the Appellate Body. 
In short, while the Appellate Body has the power to make statements or observations on general interpretative issues that are not directly related to specific disputes, it should not, and generally does not, do so in view of policy considerations.

\subsection{Nature of Interpretations}

Does the Appellate Body have the power to 'make law' in the sense that it makes binding interpretations in future cases? ${ }^{35}$ To put it differently, do pronouncements made by the Appellate Body on interpretative issues have precedential effects in the sense that they have to be followed by panels and the Appellate Body as well as by WTO Members? ${ }^{36}$

In terms of the interpretation of the WTO agreements, Article 3(2) of the DSU requires panels and the Appellate Body to interpret and apply the relevant provisions of the WTO agreements 'in accordance with customary rules of interpretation of public international law,' which are set out principally but not exclusively in Articles 31 and 32 of the Vienna Convention on the Law of Treaties (VCLT). ${ }^{37}$ Neither the rules under the DSU nor those under the VCLT explicitly provide for legal effects of reasoning and interpretation in previous Appellate Body reports.

Despite the absence of a textual basis, the Appellate Body regularly cites and follows pronouncements on interpretations in past cases, particularly its own. For example, in US - Stainless Steel, the Appellate Body stated that 'the legal interpretation embodied in adopted panel and Appellate Body reports becomes part and parcel of the acquis of the WTO dispute settlement system.'38 Additionally, the Appellate Body acknowledged that panel reports adopted under the auspices of the General Agreement on Tariffs and Trade (GATT) 1947 are also 'an important part of the GATT acquis' and 'create legitimate expectations among WTO Members, and, therefore, should be taken into account where they are relevant to any dispute. ${ }^{39}$ In US - OCTG Sunset Reviews, hav-

35 This subsection is partly based on the author's unpublished paper presented to the Midyear Meeting of the American Society of International Law in 2016.

$3^{6}$ This subsection does not discuss legal effects of conclusions and recommendations made by the Appellate Body on the disputing parties to a specific dispute.

37 Vienna Convention on the Law of Treaties 1155 UNTS 331 (VCLT). See WTO, United States - Standards for Reformulated and Conventional Gasoline, Report of the Appellate Body (29 April 1996) WT/DS2/AB/R, 17; WTO, Japan - Taxes on Alcoholic Beverages, Report of the Appellate Body (4 October 1996) WT/DS8/AB/R, WT/DS1o/AB/R, WT/ $\mathrm{DS}_{11} / \mathrm{AB} / \mathrm{R}, 10-12$.

38 US - Stainless Steel from Mexico (n 19) para 160.

39 Japan - Taxes on Alcoholic Beverages (n 37) 14. See also WTO, United States - Definitive Safeguard Measures on Imports of Circular Welded Carbon Quality Line Pipe from Korea, Report of the Appellate Body (15 February 2002) WT/DS202/AB/R, para 174. 
ing noted a 'distinct' role of the Appellate Body in developing 'a coherent and predictable body of jurisprudence, ${ }^{40}$ the Appellate Body stated that 'following the Appellate Body's conclusions in earlier disputes is not only appropriate, but is what would be expected from panels, especially where the issues are the same.'41 The Appellate Body also insisted that '[e]nsuring 'security and predictability' in the dispute settlement system, as contemplated in Article 3(2) of the DSU, implies that, absent cogent reasons, an adjudicatory body will resolve the same legal question in the same way in a subsequent case. ${ }^{42}$ Moreover, regarding the function of panels, the panel in US - Continued Zeroing stated that its mandate under Article 11 of the DSU to conduct an 'objective assessment of the matter' before it requires careful consideration of earlier decisions of panels and the Appellate Body, together with the facts and arguments made by the parties in the dispute before it. ${ }^{43}$ These findings suggest that the Appellate Body's pronouncements on interpretations have precedential effects in the sense that WTO Members have legitimate expectations that they will be followed by panels and the Appellate Body in future cases absent cogent reasons. ${ }^{44}$ It should be added though that the precedential effects must be distinguished from stare decisis effects in that the former is considered de facto authoritative by subsequent panels, but does not have any binding effects.

Having confirmed the precedential effects of the Appellate Body's interpretations on panels and the Appellate Body, it is important to distinguish these from the effects of such interpretations on WTO Members. More specifically, the fact that panels and the Appellate Body are expected to follow the Appellate Body's previous interpretations does not necessarily mean that WTO Members are also expected to follow them. While the legitimate expectation that panels and the Appellate Body follow the Appellate Body's previous interpretative pronouncements are derived from the principal objective of the dispute settlement system to provide 'security and predictability to the multilateral trading system,' the expectation that WTO Members do the same cannot be inferred from that objective. On the contrary, expecting WTO Members to follow the Appellate Body's pronouncements on interpretations would undermine their 'rights ... to seek authoritative interpretation

40 WTO, United States - Sunset Reviews of Anti-Dumping Measures on Oil Country Tubular Goods from Argentina, Report of the Appellate Body (29 November 2004) WT/DS268/ $\mathrm{AB} / \mathrm{R}$, para 161 .

41 ibid para 188.

42 ibid para 160.

43 WTO, United States - Continued Existence and Application of Zeroing Methodology, Report of the Panel (1 October 2008) WT/DS $350 / \mathrm{R}$, para 7.180.

44 Ingo Venzke, How Interpretation Makes International Law: On Semantic Change and Normative Twists (OUP 2012) 167-72. 
of provisions of' the WTO agreements in accordance with Article 3(9) of the DSU. Apart from 'authoritative' interpretations that are to be adopted pursuant to Article IX:2 of the Marrakesh Agreement Establishing the World Trade Organization (Marrakesh Agreement), ${ }^{45}$ nothing in the WTO agreements presupposes the hierarchy between interpretations by WTO Members and those by the Appellate Body. ${ }^{46}$ Moreover, given that each WTO Member's consent to the WTO agreements forms the very basis of the binding force of the WTO agreements on that Member, each Member should be considered to have the inherent power to interpret the WTO agreements. ${ }^{47}$ Such inherent power of a Member is not without limits in the sense that the Member would be required to withdraw or modify measures based on its own interpretation of the WTO agreements if the Appellate Body disagrees with that interpretation and finds the measures based on such an interpretation inconsistent with the WTO agreements. Nevertheless, the Member cannot be deprived of the power to disagree with the Appellate Body's interpretation and hold to its own interpretation.

A remaining question is how WTO Members can exercise their power to disagree with the Appellate Body's interpretation and make their own interpretations. A mechanism that allows WTO Members to exercise such power will be discussed in the following sections.

\section{3}

\section{Members' Power to Disagree with the Appellate Body Under the Current WTO Agreements}

The previous section argues that, while interpretations made by the Appellate Body are expected to be followed by panels and the Appellate Body in future cases, they do not deprive WTO Members of their power to disagree with the Appellate Body's interpretations and make their own interpretations.

This section discusses the existing mechanisms by which Members may exercise such power. In particular, this section assesses the potential benefits and limits of the 'exclusive authority' under Article IX:2 of the Marrakesh Agreement to adopt interpretations as well as those of 'subsequent agreement' or 'subsequent practice' in the meaning of Article 31(3)(a) and (b) of the VCLT.

45 Agreement Establishing the World Trade Organization (1 January 1995) 1867 UNTS 154 (Marrakesh Agreement).

46 Japan - Taxes on Alcoholic Beverages (n 37) 13.

47 Cf Jean Combacau and Serge Sur, Droit International Public (LGDJ 2016) 171. 


\subsection{Members' Exclusive Authority to Adopt Interpretations}

The most evident and important mechanism by which WTO Members may pronounce interpretations is the procedures under Article IX:2 of the Marrakesh Agreement, which confers upon ' $t$ the Ministerial Conference and the General Council ... the exclusive authority to adopt interpretations of this Agreement and of the Multilateral Trade Agreements.' While Members cannot use the procedures under Article IX:2 to amend provisions of the WTO agreements because that would 'undermine the amendment provisions in Article X' of the Marrakesh Agreement, ${ }^{48}$ they can adopt an 'authoritative interpretation' to clarify provisions of the WTO agreements.

According to Article 3(9) of the DSU, the provisions of the DSU 'are without prejudice to the rights of Members to seek authoritative interpretation' pursuant to Article IX:2 of the Marrakesh Agreement. Thus, any legal effects that the Appellate Body's interpretations may have under the DSU cannot interfere with the exclusive authority of the Ministerial Conference and the General Council under the provision. For example, the Ministerial Conference and the General Council may adopt an 'authoritative interpretation' that overrides an interpretation previously made by the Appellate Body. Since interpretations adopted pursuant to Article IX:2 are binding upon the WTO Members, ${ }^{49}$ and, as such, binding upon the Appellate Body, they shall therefore be followed by the Appellate Body regardless of its own previous interpretations. ${ }^{50}$ To put it differently, Article IX:2 enables WTO Members not only to disagree with interpretations by the Appellate Body but also to correct them.

Despite the potentially critical impact of the 'authoritative interpretation,' the procedures under Article IX:2 have to date never been used. The lack of use may be attributed to several factors, but the high procedural threshold for the adoption of an 'authoritative interpretation' is the most critical obstacle. According to Article IX:2, Second and Third Sentences, of the Marrakesh Agreement, a decision to adopt such interpretation 'shall be taken by a threefourths majority of the Members' 'on the basis of a recommendation by the

48 Marrakesh Agreement, art IX(2).

49 US - Stainless Steel from Mexico (n 19) para 158, fn 308.

50 To what extent an 'authoritative interpretation' limits the Appellate Body's interpretative power is another question. For example, the Ministerial Conference may adopt a decision that a certain provision of the WTO Agreement shall be interpreted to mean that WTO Members have a certain obligation. Pursuant to the decision, panels and the Appellate Body have no choice but to interpret the provision as decided by the Ministerial Conference. In the meantime, the Ministerial Conference may decide that a certain provision of the WTO Agreement shall not be interpreted to mean that WTO Members have a certain obligation. Such a decision excludes one interpretation of the provision but may leave discretion as to the interpretation by panels and the Appellate Body. 
Council overseeing the functioning of that Agreement.' Moreover, in light of the utmost importance of consensus in the WTO, the Council would have to achieve consensus of all the WTO Members and avoid voting to make such a sensitive decision. Needless to say, consensus on what interpretation to adopt is clearly more difficult than consensus on whether to adopt an interpretation. ${ }^{51}$ The failure of a few attempts ${ }^{52}$ to use the procedures also indicates the general caution of WTO Members toward adopting an 'authoritative interpretation.' The concern of the United States about the Appellate Body's extensive de facto authority might be justified at least partly by the impracticability of the procedures under Article IX:2.

\subsection{Subsequent Agreement and Subsequent Practice Under Article $31(3)(a)$ and (b) of the VCLT}

The impracticability of the procedures under Article IX:2 of the Marrakesh Agreement does not mean that WTO Members are left with no means to pronounce their positions on an interpretation. In EC - Chicken Cuts, the Appellate Body acknowledged that 'the existence of Article IX:2 of the [Marrakesh] Agreement is not dispositive for resolving the issue of how to establish the agreement by Members'53 on interpretative questions. For example,

51 Members may also disagree on what constitutes an interpretation and not an amendment. Ehlermann \& Ehring (n 8) 805-06, 813-17.

52 For example, the EC requested an authoritative interpretation pursuant to the provision in relation to the question of sequencing between Articles 21(5) and 22(6) of the DSU. WTO, Request for an Authoritative Interpretation Pursuant to Article IX:2 of the Marrakesh Agreement Establishing the World Trade Organization: Communication from the European Communities, General Council (25January 1999)WT/GC/W/133. However, it met with fierce opposition from the United States. WTO, Procedures for Amendment and Interpretation of the Dispute Settlement Understanding: Response to European Communities' Request for an Authoritative Interpretation of the Dispute Settlement Understanding Pursuant to Article IX:2 of the WTO Agreement: Communication from the United States, General Council (5 February 1999) WT/GC/W/144. More recently, Russia proposed to adopt an authoritative decision with respect to the interpretation of security exceptions under Article XXI of the GATT. WTO, Proposal on MCio Ministerial Declaration (Russian Federation) - Part III, Ministerial Conference, Tenth Session (13 November 2015) WT/ $\operatorname{MIN}(15) / \mathrm{W} / 14$, para 1.5. It was also proposed, in connection with the matter of reappointment of an Appellate Body member, that the 'exclusive authority' could be used to bind the Appellate Body's interpretations in future cases. See WTO, Minutes of Meeting Held in the Centre William Rappard on 23 May 2016 (Statement of Chinese Taipei), Dispute Settlement Body (29 August 2016) WT/DSB/M/379, para 6.25. None of the proposals resulted in concrete actions by the Ministerial Conference or the General Council.

53 WTO, European Communities - Customs Classification of Frozen Boneless Chicken Cuts, Report of the Appellate Body (12 September 2005) WT/DS269/AB/R, WT/DS286/AB/R, para 273 . 
Members may adopt decisions on interpretative questions at meetings of WTO Councils and Committees or Ministerial Conferences. These decisions shall be taken into account by panels and the Appellate Body if they constitute 'subsequent agreement between the parties regarding the interpretation of the treaty or the application of its provisions' within the meaning of Article 31(3)(a) of the VCLT. Subsequent agreement can be particularly useful for interpretative questions involving terms in the WTO agreements that are 'by definition, evolutionary. ${ }^{54}$ That is, because the meaning of an 'evolutionary' term may change from what was understood at the time of the conclusion of the WTO agreements, an agreement may be adopted subsequently to clarify the evolved meaning of the term.

In the WTO, Members may reach a 'subsequent agreement' in several different forms. In particular, Members may adopt a ministerial decision that clarifies an interpretation of a provision of the WTO agreements. ${ }^{55}$ For example, in US - Clove Cigarettes, the Appellate Body examined the legal effect of a decision adopted at the Doha Ministerial Conference, ${ }^{56}$ which clarifies an interpretation of the term 'reasonable interval' as provided in Article 2(12) of the TBT Agreement. Having noted that the decision does not constitute an 'authoritative interpretation' in the sense of Article IX:2 of the Marrakesh Agreement and Article 3(9) of the DSU, ${ }^{57}$ the Appellate Body recalled that

Article IX:2 of the WTO Agreement does not preclude panels and the Appellate Body from having recourse to a customary rule of interpretation

54 WTO, United States - Import Prohibition of Certain Shrimp and Shrimp Products, Report of the Appellate Body (12 October 1998) WT/DS58/AB/R, para 130, citing Legal Consequences for States of the Continued Presence of South Africa in Namibia (South West Africa) Notwithstanding Security Council Resolution 276 (1970), Advisory Opinion [1971] ICJ Rep 16, para 53 .

55 Evidently, a ministerial decision that does not constitute an 'agreement... bearing specifically upon the interpretation of' the WTO Agreement cannot be considered a 'subsequent agreement.' WTO, European Communities - Regime for the Importation, Sale and Distribution of Bananas, Second Recourse to Article 21.5 of the DSU by Ecuador; European Communities - Regime for the Importation, Sale and Distribution of Bananas, Recourse to Article 21.5 of the DSU by the United States, Reports of the Appellate Body (26 November 2008) WT/DS 27/AB/RW2/ECU, WT/DS27/AB/RW/USA, paras 389-93; WTO, Peru Additional Duty on Imports of Certain Agricultural Products, Report of the Appellate Body (20 July 2015) WT/DS457/AB/R, paras 5.100- 5.105.

$5^{6}$ Ministerial Conference, Fourth Session, Doha, 9-14 November 2001, ImplementationRelated Issues And Concerns, Decision of 14 November 2001 (20 November 2001) WT/ $\operatorname{MIN}(01) / 17$, para 5.2 .

57 WTO, United States - Measures Affecting the Production and Sale of Clove Cigarettes, Report of the Appellate Body (4 April 2012) WT/DS406/AB/R, paras 250-55. 
of public international law that, pursuant to Article 3.2 of the DSU, they are required to apply. ${ }^{58}$

The Appellate Body further acknowledged that

a decision adopted by Members, other than a decision adopted pursuant to Article IX:2 of the WTO Agreement, may constitute a "subsequent agreement" on the interpretation of a provision of a covered agreement under Article $31(3)$ (a) of the Vienna Convention. ${ }^{59}$

On that basis, the Appellate Body concluded that

paragraph 5.2 of the Doha Ministerial Decision can be characterized as a "subsequent agreement" within the meaning of Article 31(3)(a) of the Vienna Convention, provided that it clearly expresses a common understanding, and an acceptance of that understanding among Members with regard to the meaning of the term "reasonable interval" in Article 2.12 of the TBT Agreement. ${ }^{60}$

Moreover, decisions adopted at meetings of WTO Councils and Committees may constitute subsequent agreement under certain circumstances. In this regard, in US - Tuna II (Mexico), the Appellate Body discussed the relevance of the decision adopted by the Committee on Technical Barriers to Trade (TBT Committee) on Principles for the Development of International Standards, Guides and Recommendations with Relation to Articles 2, 5 and Annex 3 of the Agreement (TBT Committee Decision), ${ }^{61}$ which sets out principles and procedures that standardizing bodies should observe when developing international standards. ${ }^{62}$ The Appellate Body found that the TBT Committee Decision can be considered a subsequent agreement within the meaning of Article 31(3)(a) of the VCLT on the basis that the Decision was adopted 'subsequent to the

58 ibid para 258 (emphasis in the original).

59 ibid para 260.

6o ibid para 267 .

61 WTO TBT Committee, 'Decisions and Recommendations Adopted by the WTO Committee on Technical Barriers to Trade Since 1 January 1995', Note by the Secretariat: Revision (8 March 2017) G/TBT/1/Rev.13, 54-56.

62 WTO, United States - Measures Concerning the Importation, Marketing and Sale of Tuna and Tuna Products, Report of the Appellate Body (16 May 2012) WT/DS381/AB/R, para 366. 
conclusion of the TBT Agreement' and 'by consensus' at a meeting of the TBT Committee, which 'comprises all WTO Members. ${ }^{63}$

Generally speaking, given the limited impact of decisions adopted at WTO Councils and Committees, WTO Members might see fewer obstacles in reaching consensus to adopt such decisions than in making binding decisions. Nevertheless, given that a decision by Members on an interpretative question would be most needed when the question is controversial, reaching a consensus to adopt a decision on an interpretative question at Councils and Committees would not be easier than adopting an authoritative interpretation. In particular, it is almost inconceivable that the Members would agree by consensus that a certain interpretation of the WTO agreements made by the Appellate Body in a specific case needs to be corrected or replaced by another interpretation.

Even if the Members fail to agree by consensus on a certain interpretation, they may still engage in certain conduct to indicate their positions on said interpretation. In this regard, Article $31(3)(\mathrm{b})$ of the VCLT provides that '[a]ny subsequent practice in the application of the treaty which establishes the agreement of the parties regarding its interpretation' 'shall be taken into account.' Thus, for example, the reactions of Members to a pronouncement by the Appellate Body on an interpretative issue may accumulate to form a 'subsequent practice' that evidences their common understanding that the pronouncement is not accepted by the WTO Members and should therefore not be followed in future cases.

However, the Appellate Body has been cautious about acknowledging the existence of subsequent practice within the meaning of Article 31(3)(b). In EC - Chicken Cuts, the Appellate Body first noted that Article IX:2 of the Marrakesh Agreement would not 'impinge upon recourse to subsequent practice as a tool of treaty interpretation under Article 31(3)(b) of the Vienna Convention. ${ }^{64}$ In the meantime, the Appellate Body insisted that 'the essence of subsequent practice in interpreting a treaty has been recognized as a "concordant, common and consistent" sequence of acts or pronouncements which is sufficient to establish a discernable pattern implying the agreement of the parties regarding its interpretation' and that '[a]n isolated act is generally not sufficient to establish subsequent practice. ${ }^{65}$ Thus, according to the Appellate Body, absent 'a discernible pattern of acts or pronouncements implying an agreement among WTO Members on' an interpretative issue, there is no subsequent practice within the meaning of Article 31(3)(b) of the

\footnotetext{
63 ibid para 371.

64 EC-Chicken Cuts (n 53) para 273.

65 Japan - Taxes on Alcoholic Beverages (n 37) 13.
} 
VCLT. ${ }^{66}$ Moreover, in EC - Chicken Cuts, the Appellate Body cautioned that the "lack of reaction" should not be read lightly, without further inquiry into attendant circumstances of a case, to imply agreement with an interpretation by treaty parties that have not themselves engaged in a particular practice followed by other parties in the application of the treaty. ${ }^{67}$ Pursuant to this cautious approach, in US - Gambling, the Appellate Body refused to acknowledge that the 2001 Guidelines, ${ }^{68}$ 'in and of themselves, constitute "subsequent practice" within the meaning of Article 31(3)(b) of the Vienna Convention,' by highlighting the fact that, although it was adopted by the Council for Trade in Services by consensus, ${ }^{69}$ the Council 'explicitly stated that they were to be "non-binding"' and 'shall not modify any rights or obligations of the Members under the GATS'70 Under the Appellate Body's cautious criteria, the chance that reactions of WTO Members to an interpretation by the Appellate Body would form a 'subsequent practice' is extremely slim.

A New Mechanism to Allow Members to Disagree with the Appellate Body's Interpretations

This section proposes a new mechanism that would be built upon 'interpretative declarations' under general international law and allow WTO members to disagree with interpretations by the Appellate Body and pronounce their own interpretations of the WTO agreements. It first examines interpretative declarations under general international law, and then discusses how the new mechanism may be designed and implemented in the WTO.

\subsection{Interpretative Declarations Under General International Law}

The VCLT does not explicitly provide for rules on interpretative declarations, but the Guide to Practice on Reservations to Treaties (Guide), adopted by the International Law Commission (ILC) in 2011 and taken note of by the

66 WTO, Chile - Price Band System and Safeguard Measures Relating to Certain Agricultural Products, Report of the Appellate Body (23 September 2002) WT/DS207/AB/R, para 214.

67 ibid para 273 .

68 WTO, Guidelines for the Scheduling of Specific Commitments Under the General Agreement on Trade in Services (GATS) (Adopted by the Council for Trade in Services on 23 March 2001, published 28 March 2001) S/L/92.

69 WTO, 'Council for Trade in Services: Report of the Meeting Held on 23 March 2001', Note by the Secretariat (14 May 2001) S/C/M/52, paras 4-11.

70 WTO, United States - Measures Affecting the Cross-Border Supply of Gambling and Betting Services, Report of the Appellate Body (7 April 2005) WT/DS285/AB/R, para 193. 
General Assembly in 2013, stipulates various guidelines as to interpretative declarations. ${ }^{71}$

First of all, Guideline 1.2 of the Guide defines an interpretative declaration as 'a unilateral statement, however phrased or named, made by a State or an international organization, whereby that State or that organization purports to specify or clarify the meaning or scope of a treaty or of certain of its provisions. ${ }^{.72}$ According to Guideline 3.5 of the Guide, '[a] State ... may formulate an interpretative declaration unless the interpretative declaration is prohibited by the treaty.' This guideline reflects the notion that States have the inherent power to interpret an international law rule to which they consent, ${ }^{73}$ although such power may be subject to limits. ${ }^{74}$

It is important to clearly distinguish an interpretative declaration from a reservation, which is defined as a 'unilateral statement, however phrased or named, made by a State, when signing, ratifying, accepting, approving, or acceding to a treaty, whereby it purports to exclude or to modify the legal effect of certain provisions of the treaty in their application to that State. ${ }^{75}$ While the former 'may only specify or clarify the meaning or scope which its author attributes to a treaty or to certain provisions thereof, ${ }^{\prime 76}$ the latter would effectively constitute amendments to the treaty that are applicable only to the contracting States that have made the reservation. While a treaty rarely limits interpretative declarations, reservations are often subject to conditions under a treaty or may even be prohibited by it.

Interpretative declarations are, by nature, unilateral and may be formulated by individual States. That said, States are not prevented from jointly formulating an interpretative declaration, ${ }^{77}$ which is not uncommon in practice. ${ }^{78}$ Although rare, an interpretative declaration that is unilaterally formulated

71 ILC, Report of the International Law Commission on the Work of Its 63rd Session (26 April-3 June and 4 July-12 August 2011) A/66/10/Add.1

72 ibid Guideline 1.2.

73 The Permanent Court of International Justice (PCIJ) confirmed that 'le droit d'interpréter authentiquement une règle juridique appartient à celui-là seul qui a le pouvoir de la modifier ou de la supprimer' by citing the traditional principle ejus est interpretare legem cujus condere. Publications de la Cour Permanente de Justice Internationale (le 6 décembre 1923) PCIJ Rep Series B No 8, Recueil des Avis Consultatifs, Affaire de Jaworzina (Frontière Polono-Tchécoslovaque) 37. See also Combacau and Sur (n 47) 171.

74 For example, an interpretative declaration may be prohibited or limited by a relevant treaty. Alternatively, an interpretation may be found to result in an impermissible reservation by a judicial organ.

75 VCLT, art 2(1)(d).

76 ILC Report 2011 (n 71), Guideline 4.7.1(1).

77 ibid Guideline 1.2.1.

78 ibid Commentary to Guideline 1.2.1, paras 2, 3 . 
by an individual State may be later approved or disapproved by other States. ${ }^{79}$ Although the approval of or opposition to an interpretative declaration by other States may be inferred from their conduct, ${ }^{80}$ an approval shall not be inferred from the mere silence of the other States. ${ }^{81}$

Given the inherent nature of States' power to formulate interpretative declarations, States retain wide discretion as to when and how to formulate the declarations. As to the timing, while a reservation is made at the time of 'signing, ratifying, accepting, approving or acceding to a treaty,' an interpretative declaration may be formulated 'at any time,' according to Guideline 2.4.4. ${ }^{82}$ For example, an interpretative declaration may be made after a treaty comes into force and a third body, such as a judicial organ, provides an interpretation of the treaty. ${ }^{83}$ There is no legal requirement of writing, although an interpretative declaration should preferably be formulated in writing ${ }^{84}$ so that it may be widely publicized. ${ }^{85}$ In general, States may modify or withdraw an interpretative declaration at any time ${ }^{86}$ unless they are prevented from doing so by the principle of estoppel. ${ }^{87}$

The probative value of interpretative declarations is limited compared to 'authentic' means of interpretation, which shall be taken into account in the interpretation. It should be recalled that the principal purpose of treaty

79 Cf ibid Guidelines 2.9.1, 2.9.2. If an interpretative declaration is approved by all the contracting States to a treaty, such a declaration may constitute a subsequent agreement under Article 31(3)(a) of the VCLT; ibid Guideline 4.7.3.

$80 \quad$ ibid Guideline 2.9.8.

81 ibid Guideline 2.9.9. See also Frank Horn, Reservations and Interpretative Declarations to Multilateral Treaties (Elsevier 1988) 244.

82 ibid Guideline 2.4.4 includes a phrase '[w]ithout prejudice to the provisions of guidelines 1.4 and 2.4.7, but Guidelines 1.4 and 2.4.7 are inapplicable to the WTO context for the following reasons. First, Guideline 1.4 provides for rules concerning a conditional interpretative declaration that is defined as a unilateral statement formulated by a State, whereby the State 'subjects its consent to be bound by the treaty to a specific interpretation of the treaty or of certain provisions thereof.' Considering the close affinity between conditional interpretative declarations and reservations, it is evident that conditional interpretative declarations are prohibited under WTO law for the same reason that reservations are prohibited. See Commentary to Guideline 1.4, paras 12,13. Second, while Guideline 2.4.7 states that ' $[\mathrm{w}]$ here a treaty provides that an interpretative declaration may be formulated only at specified times, a State ... may not formulate an interpretative declaration concerning that treaty subsequently,' nothing in the WTO Agreement, including the DSU, limits the timing of formulating interpretative declarations.

83 ibid Commentary to Guideline 1.2, para 23.

84 ibid Guideline 2.4.1.

85 ibid Commentary to Guideline 2.4.1, para 2.

86 ibid Guidelines 2.4.8, 2.5.12.

87 ibid Commentary to Guideline 2.4.4, para 4. 
interpretation is to ascertain the common understanding of the parties to a treaty as to the meaning of the treaty or relevant terms of the treaty. In other words, the interpretation has to primarily search for the 'objective' meaning of the treaty or the terms thereof that reflect the intention of all the parties to the treaty. In the meantime, an interpretation pronounced by an individual State's interpretative declaration reflects the 'meaning or scope' as attributed by that State and, therefore, necessarily comprises a 'subjective' element. Thus, the 'meaning or scope' of a treaty or its provisions clarified by an interpretative declaration is not conclusive about the common understanding of the parties as to the 'meaning and scope. 88

Nevertheless, this does not mean that the 'subjective' intention of an individual or several parties to a treaty cannot be taken into account in the interpretation of the treaty. ${ }^{89}$ In this regard, Article 32 of the VCLT acknowledges that ' $[r]$ ecourse may be had to supplementary means of interpretation.' By way of example, the provision states that 'the preparatory work of the treaty and the circumstances of its conclusion' are included in the supplementary means of interpretation. This reflects the recognition that, while the 'preparatory work of the treaty and the circumstances of its conclusion' do not directly evidence the common understanding of the parties as to the meaning of a treaty, they show the subjective intentions of some parties, which may in turn shed light on the meaning of the treaty under certain circumstances. ${ }^{90}$ Importantly, the supplementary means are not limited to the 'preparatory work of the treaty and the circumstances of its conclusion' that are explicitly mentioned in the provision. ${ }^{91}$ In particular, an interpretative declaration may be taken into account as 'further' or 'supplementary' means of interpretation ${ }^{92}$

88 Robert Jennings and Arthur Watts, 'Interpretation of Treaties' in Robert Jennings and Arthur Watts (eds), Oppenheim's International Law, vol 1 (9th ed, OUP, 2008) 1268; DW Greig, 'Reservations: Equity as a Balancing Factor?' (1995) 16 Australian Yearbook International Law 21, 37-38. See also Commentary to Draft Article 69, para 13, International Law Commission Yearbook 1964 Volume II, A/CN.4/SER.A/1964/ADD.1, 204.

89 Cf DM McRae, 'The Legal Effect of Interpretative Declarations' (1979) 49 BYIL155, 169-70.

9o International Law Commission Yearbook, 1966, Vol II, Commentary to arts 27, 28, para 10, 218.

91 Supplementary means of interpretation listed in art 32 of the VCLT are not exhaustive. Mustafa Kamil Yasseen, 'L'interprétation des traités d'après la Convention de Vienne sur le droit des traités' (1976-III) Recueil des cours 1, 79.

92 ILC Report 2011 (n 71), Guideline 4.7.1(1); See also Commentary to Draft Article 69, para 13, International Law Commission Yearbook 1964 Volume II, A/CN.4/SER.A/1964/ADD.1, 204; ILC, Report of the International Law Commission on the Work of 68th Session (2 May-10 June and 4 July-12 August 2016) A/71/10, Commentary to Draft Conclusion 10, para 10, 129 . 
within the meaning of Article 32 of the VCLT to corroborate or support an interpretation that has already been determined by other methods. ${ }^{93}$ The probative value of an interpretative declaration is particularly significant when it is jointly formulated by several parties or when it is unilaterally formulated but later approved by other parties. ${ }^{94}$

\subsection{New Mechanism in the WTO}

This subsection proposes a new mechanism under which WTO Members may formulate interpretative declarations and disagree with the Appellate Body's interpretation. It also argues that the interpretative declarations may be taken into account by the Appellate Body as a supplementary means of interpretation under the VCLT. ${ }^{95}$ Interpretative declarations are not meant to directly correct or override interpretations made by the Appellate Body, but allow Members to at least pronounce their disagreement with the Appellate Body in a more meaningful way than simply 'express[ing] their views' at DSB meetings. The remaining part of the subsection discusses how the new mechanism should be designed and implemented in the WTO.

First, it should be recalled that the WTO agreements do not explicitly prohibit interpretative declarations, similar to most other treaties. ${ }^{96}$ In addition, the previous sections of this paper have pointed out that the WTO Members have the inherent power to interpret the WTO agreements, although the existing mechanisms in the WTO fail to allow them to exercise the power effectively. Based on the lack of explicit prohibition under the WTO agreements and the Members' inherent power to interpret the WTO agreements, it can be concluded that Members have that power, albeit implicit, to formulate interpretative declarations concerning the WTO agreements. ${ }^{97}$

Considering the lack of practice of interpretative declarations in the WTO until now, it would be useful to insert explicit language that acknowledges the right of Members to formulate interpretative declarations. For example, a new sentence may be inserted after the Fourth Sentence of Article IX:2 of the Marrakesh Agreement, which would provide that 'this

93 ILC Report 2011 (n 71), Commentary to Guideline 4.7.1, paras 26, 31.

94 ibid Guideline 4.7.1(2).

95 Cf WTO, United States - Continued Existence and Application of Zeroing Methodology, Report of the Appellate Body (4 February 2009) WT/DS35o/AB/R, para 268 ('treaty interpretation is an integrated operation' and interpretative rules or principles must be understood and applied 'in a holistic fashion.').

96 By way of exception, a few regional trade agreements concluded by Canada explicitly prohibit reservations and interpretative declarations. See Canada - Korea FTA, art 23.3; Canada - Costa Rica FTA, art XV.3.

ILC Report 2011 (n 71), Commentary to Guideline 3.5, para 13. 
paragraph shall not be construed to prevent a Member from formulating an interpretative declaration. ${ }^{98}$ Another more restrictive way to explicitly acknowledge Members' right to formulate interpretative declarations would be to amend the second sentence of Article 17(14) of the DSU to read " $[t]$ his adoption procedure is without prejudice to the right of Members to express their views on an Appellate Body report or to formulate an interpretative declaration in response to the Appellate Body's pronouncement on an interpretative issue.' This latter amendment is more properly calibrated to the current concern of the United States than the former because it presupposes that Members may formulate interpretative declarations when the Appellate Body interprets the WTO agreements erroneously in the eyes of Members. Nevertheless, given that the WTO agreements implicitly allow WTO Members to formulate interpretative interpretations, the new mechanism can also be implemented without having to amend the WTO agreements.

Regardless of whether the WTO agreements would be amended, working procedures would have to be adopted by the DSB to stipulate how WTO Members may formulate an interpretative declaration. Presumably, adopting such procedures by consensus is not an insurmountable task as long as the WTO Members agree that they have the right to formulate interpretative declarations.

For example, the working procedures should clarify that an interpretative declaration may be formulated either unilaterally by an individual Member or jointly by several Members. Considering the limited probative value of an interpretative declaration by an individual Member, it may be useful for the working procedures to encourage Members to consult with each other to make a joint declaration. When an interpretative declaration is formulated by an individual Member, it would be desirable for other Members to react by expressing their views. For that purpose, the working procedures could provide that an interpretative declaration that is newly formulated should be placed by a declaring Member on the agenda of a DSB meeting following the declaration.

The working procedures should also provide that interpretative declarations be made in writing and notified to the WTO Secretariat. This is particularly important in the WTO because Members make various unilateral statements without attaching any legal effect to them ${ }^{99}$ and interpretative

\footnotetext{
98 Alternatively, a sentence could be inserted in Article XIV:1 of the Marrakesh Agreement that would explicitly prohibit reservations while simultaneously acknowledging the right of Members to formulate interpretative declarations. 
declarations should be clearly distinguishable from these non-legal statements. In other words, an interpretative declaration should be formulated on limited occasions through formal procedures with clear recognition by a declaring Member that the declaration would have a certain legal consequence. Moreover, the Secretariat should be required to properly register the notified interpretations so that other Members may easily access and react to them. ${ }^{100}$ While the withdrawal or modification of an interpretative declaration should not be prohibited, the procedural requirements equivalent to the formulation of a declaration should be followed to ensure that a declaration is not withdrawn or modified capriciously.

To avoid the abuse of interpretative declarations, the working procedures could stipulate the timing of formulation of interpretative declarations. More specifically, Members should be allowed to formulate interpretative declarations only in response to an interpretation by the Appellate Body. A Member would thus not be allowed to formulate interpretative declarations continuously on unlimited issues, but may be allowed to do so as a 'counter-proposal' to the Appellate Body's interpretation with which a particular Member disagrees. ${ }^{101}$ The working procedures should also ensure that interpretative declarations shall not deprive the binding effects of rulings and recommendations of the Appellate Body in specific cases.

The definition of an interpretative declaration should be clarified as much as possible in the working procedures. In this regard, it is essential to ensure that a Member would not seek to formulate a reservation under the guise of an interpretative declaration. A statement made by a Member, however phrased or named, that purports 'to exclude or to modify' the legal effect of certain provisions of the WTO agreements in the application to that Member constitutes a reservation and clearly violates the rules under the WTO agreements, in particular Articles X and XIV:1 of the Marrakesh Agreement. An interpretative declaration should be limited to the purpose of 'specifying or clarifying' provisions of the WTO agreements. In cases in which a concern arises that an interpretative declaration formulated by a Member in fact constitutes a reservation, other Members may raise the concern at a DSB meeting and disapprove the declaration. While the disapproval of other Members does not

100 Cf Treaty Section of the Office of Legal Affairs, 'Summary of Practice of The SecretaryGeneral as Depositary of Multilateral Treaties' (1999) UN Doc ST/LEG/7/Rev.1, para 218.

101 ILC Report 2011 (n 71), Commentary to Guideline 1.2, para 28. 
automatically deny the validity of the declaration, ${ }^{102}$ it would significantly reduce the probative value of the declaration.

If a Member takes a measure based on the declared interpretation that is disapproved by other Members on the grounds that it modifies the legal effect of certain WTO obligations and therefore constitutes a reservation, other Members may decide to have recourse to WTO dispute settlement, claiming that the measure is based on an impermissible interpretation of the WTO agreements and therefore violates them. In reviewing the consistency of the measure with the WTO agreements, the Appellate Body would be required to examine whether the declared interpretation that underlies the measure is permissible. If the Appellate Body concludes that the declared interpretation is impermissible and therefore the measure is inconsistent with the WTO agreements, the respondent Member, i.e., the author of the declaration, has a legal obligation to follow the Appellate Body's rulings and recommendations on the specific dispute even if it disagrees with the interpretation of the Appellate Body. ${ }^{103}$

The working procedures should also stipulate the legal consequences of interpretative declarations: in particular, how the declarations may be taken into account in the interpretation of the WTO agreements by the Appellate Body. This issue is of utmost importance to achieve a proper check and balance in WTO dispute settlement. On one hand, allowing Members to correct or override the Appellate Body's interpretation by formulating an interpretative declaration would undermine the essential impartiality and independence of the Appellate Body. In this regard, the preceding paragraph suggests that interpretative declarations are not binding on the Appellate Body. ${ }^{104}$ On the other hand, if interpretative declarations have no legal consequences, they, similar to other existing mechanisms, would fail to counterbalance the de facto authoritative power of the Appellate Body. To achieve a proper balance between the Appellate Body's independence and the WTO Members' monitoring, interpretative declarations by Members need to be given some probative value in the interpretation of the Appellate Body.

To further clarify the probative value of interpretative declarations, it is useful to first review the objective of interpretation in WTO dispute settlement. As has been confirmed on a number of occasions, the core objective of the interpretation of the WTO agreements is to find the common understanding

102 It is simply an indication of a Member's view on an interpretation. Cf McRae (n 89) 160-61.

103 Cf Belilos v Switzerland, App No 10328/83 (Commission Decision, 7 May 1986) para 102.

104 Cf McRae (n 89) 160. 
of the WTO Members regarding their meaning. For example, the Appellate Body stated in EC - Computer Equipment that " $\mathrm{t}]$ he purpose of treaty interpretation under Article 31 of the Vienna Convention is to ascertain the common intentions of the parties' and that ' $[t]$ hese common intentions cannot be ascertained on the basis of the subjective and unilaterally determined "expectations" of one of the parties to a treaty.'105 In Peru - Agricultural Products, the Appellate Body reiterated that the "general rule of interpretation" in Article 31 of the Vienna Convention is aimed at establishing the ordinary meaning of treaty terms reflecting the common intention of the parties to the treaty, and not just the intentions of some of the parties.'106

In this regard, it must be recalled that, while an interpretative declaration would clarify some Members' intent as to the meaning of the WTO agreements or a provision thereof, it does not necessarily reflect the common understanding of all WTO Members. This is a critical difference from an authoritative interpretation adopted pursuant to Article IX:2 of the Marrakesh Agreement or subsequent agreement and subsequent practice that evidences the common understanding of the WTO Members regarding an interpretative question. As noted in Section 3 of this paper, an authoritative interpretation adopted pursuant to Article IX:2 of the Marrakesh Agreement would be binding on the Appellate Body, and a subsequent agreement and subsequent practice within the meaning of Article 31(2)(a) and (b) of the VCLT shall be taken into account in the interpretation of the WTO agreements.

Nevertheless, the above analysis does not mean that some Members' intent is devoid of any legal significance. For example, in $E C$ - Computer Equipment, the Appellate Body did not deny that an act of a single WTO Member may be relevant, though to a limited degree, to the interpretation of the WTO agreements. ${ }^{107}$ More specifically, an interpretative declaration formulated by an individual Member may be taken into account as a supplementary means of interpretation if the Appellate Body considers it relevant. ${ }^{108}$ The Appellate Body may consider an interpretative declaration particularly relevant in cases

105 WTO, European Communities - Customs Classification of Certain Computer Equipment, Report of the Appellate Body (5June 1998)WT/DS62/AB/R, WT/DS67/AB/R, WT/DS68/ $\mathrm{AB} / \mathrm{R}$, para 84 .

106 WTO, Peru - Additional Duty on Imports of Certain Agricultural Products, Report of the Appellate Body (20 July 2015) WT/DS457/AB/R, para 5.95.

107 Cf ibid para 94.

108 The Appellate Body has confirmed that Article 32 of the VCLT 'does not define exhaustively the supplementary means of interpretation to which an interpreter may have recourse and that 'an interpreter has a certain flexibility in considering' what constitutes relevant supplementary means of interpretation in a given case. $E U$ - Chicken Cuts $\left(\mathrm{n}_{53}\right)$ para 283 . 
where such declaration has been made individually by a Member but later accepted by several other Members or where such declaration has been made jointly by several Members. ${ }^{109}$

Consideration as a supplementary means of interpretation would give interpretative declarations only a limited probative value in the Appellate Body's interpretation. In fact, the Appellate Body would rarely need to have recourse to interpretative declarations as a supplementary means of interpretation, if it considers, as is often the case, that interpretation according to Article 31 of the VCLT sufficiently clarifies the meaning of the WTO agreements. Nevertheless, it may find it useful to refer to relevant declarations to confirm the meaning resulting from the application of Article $31{ }^{110}$ Compared to the negotiating history that is, by nature, uncertain and inconclusive, an interpretative declaration could provide clearer evidence as to the common understanding of the Members especially when it is formulated by a majority of the Members and is not disapproved by any Members. Moreover, interpretative declarations could even influence the Appellate Body's interpretations under Article $3^{1}$ of the VCLT in a subtler way. Given the ambiguity of the text in many WTO provisions, Appellate Body members might refer to interpretative declarations, either explicitly or implicitly, to ascertain the ordinary meaning or the object and purpose of relevant provisions. In this way, interpretative declarations are expected to achieve a nuanced check and balance in WTO dispute settlement, without undermining the impartiality and independence of the Appellate Body. ${ }^{111}$

Finally, it is worth mentioning two proposals recently put forth by some WTO Members, which appear to share the concerns discussed in this paper. One of them proposes that the DSB, in consultation with the Appellate Body, will establish a regular dialogue channel between the DSB and the Appellate

109 ILC Report 2011 (n 71), Guideline 4.7.1(2). Cf Richard K Gardiner, Treaty Interpretation (OUP 2015) 108. On the other hand, disapproval by several Members of an interpretative declaration may evidence that an interpretation pronounced by the declaration does not reflect the common intention of the Members as to the interpretation of the WTO Agreement.

110 WTO, China - Measures Affecting Trading Rights and Distribution Services for Certain Publications and Audiovisual Entertainment Products, Appellate Body Report (21 December 2009) WT/DS $363 / \mathrm{AB} / \mathrm{R}$, paras 404-05.

111 The judicial independence should not be considered in binary terms in the sense that anything that interferes with the power of a tribunal to decide would undermine judicial independence. Robert McDougall, 'Crisis in the WTO: Restoring the WTO Dispute Settlement Function' (October 2018) CIGI Papers No 194, $11<$ www.cigionline.org/sites/ default/files/documents/Paper\%2ono.194.pdf > accessed 9 August 2019. 
Body. ${ }^{112}$ The other makes a more specific proposal to insert the following new paragraph in Article 17 of the DSU:

\section{Meetings with the Appellate Body}

Once a year, the DSB shall meet in the presence of the Appellate Body. At such meetings, any Member may express its views on adopted Appellate Body reports. The meetings shall be open to all Members and their conduct shall be respectful of the independence and impartiality of the Appellate Body. The DSB shall adopt the rules applicable to such meetings on a proposal from the Chairman of the DSB and in consultation with the Appellate Body.113

According to these proposals, this 'would provide an additional "channel of communication" where concerns with regard to some Appellate Body approaches, systemic issues or trends in the jurisprudence could be voiced.'114 The proposals pursue the same train of thought as this paper in that they seek to reflect Members' intent in the Appellate Body's jurisprudence. However, these proposals have critical shortcomings in at least two aspects. First, in terms of the format and content, the 'views' expressed under the second proposal are no different from those expressed under Articles 16(4) and 17(14) of the DSU. There is no reason to expect that the former would have a legal significance that the latter does not. Second, the direct dialogue between the Appellate Body and WTO Members at DSB meetings would risk blurring the separate roles of the judicial and the political branches of the WTO. It should not be forgotten that the success of the Appellate Body was made possible because of its independence from the Members. ${ }^{115}$

112 WTO, 'Informal Process on Matters Related to the Functioning of the Appellate Body: Communication from Japan, Australia and Chile: Revision', General Council (26 April 2019) WT/GC/W/768/Rev.1.

113 WTO, 'Communication from the European Union, China, Canada, India, Norway, New Zealand, Switzerland, Australia, Republic of Korea, Iceland, Singapore and Mexico to the General Council', General Council (26 November 2018) WT/GC/W/752.

114 ibid.

115 WTO, 'Establishment of the Appellate Body: Recommendations by the Preparatory Committee to the WTO', approved on 6 December, Sub-Committee on Institutional Procedural and Legal Matters (8 December 1994) PC/IPL/13. 


\section{5 \\ Conclusion}

This article has argued that, while interpretations made by the Appellate Body are de facto authoritative in the sense that they should be followed by panels and the Appellate Body in future cases, they do not deprive Members of their power to disagree with the Appellate Body's interpretations and make their own interpretations. It was then pointed out that the existing mechanisms under the WTO agreements have failed to allow Members to exercise such power. Against this background, this paper has proposed a new mechanism by which Members may effectively pronounce their own interpretations. The proposal might appear rather innovative but would be built upon interpretative declarations under general international law and could be introduced into the WTO with minimum or no amendment to the DSU. It would enable the reflection of Members' intent as to the meaning of the WTO agreements in the interpretation by the Appellate Body, mostly through the application of Article 32 of the VCLT. Most importantly, it would reestablish a proper check and balance in WTO dispute settlement. 